\title{
Narratives of Prison Education Students about Their Life Projects
}

\author{
Nedli Magalhães Valmorbida' ${ }^{1}$ Juan José Mouriño Mosquera², Claus Dieter Stobäus ${ }^{3}$ \\ ${ }^{1}$ Municipal Network of Education, Porto Alegre-RS, Brazil \\ ${ }^{2}$ Postgraduate Program in Education, Pro-Rectory of Postgraduate and Research, Pontifical Catholic University \\ of Rio Grande do Sul, Porto Alegre, Brazil \\ ${ }^{3}$ Postgraduate Programs in Education and in Biomedical Gerontology, Pontifical Catholic University of Rio \\ Grande do Sul-PUCRS, Porto Alegre, Brazil \\ Email: stobaus@pucrs.br
}

Received 8 June 2016; accepted 31 July 2016; published 3 August 2016

Copyright (C) 2016 by authors and Scientific Research Publishing Inc.

This work is licensed under the Creative Commons Attribution International License (CC BY).

http://creativecommons.org/licenses/by/4.0/

(c) (i) Open Access

\begin{abstract}
This article contains reflections by the authors about the Doctoral Thesis of "Valmorbida", and reflects on projects, educational and work opportunities that students of the State Center for Youth and Adults-NEEJA Alaor Antonio Terra are a school located in Central Prison of Porto Alegre-RS, Brazil, who work as a Prison educational System. They talk about their desires for when they leave the prison system, looking for opportunities and speaking about how their school experiences can be a facilitator of these expectations, by providing the education and supporting the students' perspective. They receive the proposition: What are the projects for your life and in what instances can the school assist you in achieving this task? Thirty-nine students take part in this research, covering their alphabetization and Middle School levels. The responses will be worked with Content Analysis. Participant students are referred as subject, part spontaneously task that is carried out in the classroom as conversation and redactions, set in a pedagogical proposal.
\end{abstract}

\section{Keywords}

Youth and Adult Education, Prison Education, Narratives Probabilities

\section{Introduction}

The present article intends to verify how the Prison Education School can promote, coordinate and facilitate the expectations of individuals who are temporarily deprived of freedom in confinement. It argues that the prospects that relate to school, to constitute this segregation environment, the hope of enabling subjects alternatives that 
address likely to resize the convivial relations with the family, society and integration into the labor market. We will use the terminology Prison Education, also known as Inmate Education, Correctional Education, "Within Walls School”, or Behind Bars (Valmorbida, 2016).

Consistent students' expectations of the State Center for Youth and Adult Education-NEEJA Alaor Antonio Terra, a school located in the Central Prison in Porto Alegre-RS, Brazil, with the real possibilities of the labor market can constitute one of the tasks of Prison Education School. In the project of (re)socialization of these subjects, Education can occupy major space because of the power to provide imprisoned rethink about their worldview, their projects and plans for extramural life. The school can add to the pedagogical proposal, vocational courses that address the aspirations of students and their skills.

\section{Theoretical References}

The assumptions for the preparation of this research focus on theoretical works that punctuate the likelihood of other projects for society. Thus, combining empirical knowledge sustained over a long period, and relevant theoretical considerations it is possible to envision a more just society that can offer real opportunities for all who live in it, in prison or out of it. This optimistic expectation stems from both observations as a researcher and in the testimonies of students who attend school. The proposal for a reflection on the importance of school and how it can influence the lives of people who leave the Prison System assumes a constant concern among educators, fitting to reflect on the real dimension in developing alternative students for extramural life.

One must ponder the prospects for rethinking the projects that students have on the possibilities to conduct their proposals without, however, fall into the traps that too grandiose dreams lead to leaving the prison system. Possibly, recidivism and the consequent return to the prison set up by the lack of planning of those imprisoned, when set free, because they are not supported in the proper search to your projects.

In final adolescence, several persons project their expectations in a Higher Education, such as Law, Management, Engineering, Architecture, and Physical Education. There is also the mention of going to college, without specifying it, emphasizing the idea that the only way you can get good jobs and wages.

Tavares (2009) is positioned in this regard, emphasizing that most people, not just students think of education as a means to conquer spaces in the labor market and social environment. Education, therefore, is envisioned as a way to new expectations of life.

When we look at the prison system, this universe of exclusions that houses these subjects, think of these include possibilities brings benefits to their possibilities, but think of to harmonize them to the surrounding reality is immediate and essential task for that, he left the prison grounds, do not face with the most terrible reality, yet: the exclusion of their projects. The work project synthesizes the proposal to legitimize itself in the eyes of society, and in this sense, work is the return to life socially accepted, together with other factors: family, organized and projects company.

One of the crucial problems, so who gets out of prison is the insertion in the labor market, as the passage through the prison system closes the door to future possibilities and the fact that someone has fulfilled sentence is justifiable reason not to reach the place desired in the labor market. It is thus excluded referred to the situation of marginalization, without legal conditions for survival. The prison, in turn, does not provide adequate professional and does not prepare the subject to current market conditions, being thus more an obstacle in your life.

Life projects, according to the reports of the subjects, are based on providing knowledge and legitimacy offered by the school. The transition from marginality to life socially acceptable, for the recovery of the family, access to work, to a new life, goes through school attendance. It is possible to consider that the school plays in the specific case of these students, not only the professional qualification or academic function but also the socializing institution, which will prepare them for a return to the life in the society. It is the presence of the company within reach of citizens who could be on the edge of it. The subjects verbalize their perception of social reintegration through education. More than the professionalization, the importance of school as an institution is perceived very clearly.

Recurrently, the student who are in this prison school do an exaltation the school, as general, as the only institution that offered them positive social identity, prospects for positive change in a life trajectory rather marked by failure and losses.

Freire (1971: p. 43) states "from the man's relationship with reality, resulting to be with her and be in it, for the acts of creation, recreation and decision will he streamlining your world". It is with this prerogative of building realities, changes perceived through transformative education that the egress of the penitentiary system 
plans to redo your work and family universe. Will adding to the reality that awaits you, your desires, your desires change. Not perceived as being static, but in a world of constant movement and needs to interact, move and modify what is laid, to reemerge as something to be reinvented. He feels sharer of these changes and realize the school the source of the alternatives that will lead, when confronted with society, be able to cope with the rules sometimes adulterated by the students themselves.

It is worth to question, however, we can problematize of how to cross the face of being a graduate when out of the penitentiary system, without the support of institutions that follow in their paths in search of insertion in the labor market and in schools. Freire, speculating thinking about hope brings us to human nature, as hopeful beings and the question of the incompleteness of the people. Therefore, we seek, because we are aware of our proposal that, being human, do not cease to hope. This is the mobile of students attending NEEJA, being the reading that make their incompleteness, their life prospects and educational, employment and family relationships for the future.

Emphasizes Freire (1997) that we are conditioned beings, but not certain, because we are historical beings, acting in history and rewriting it. Realizing that education takes time and social spaces, the teacher becomes one enlightening person of realities, not hindering change, but encouraging them.

Highlights the author that hope is the moving of the searches and the story is built through the searches, the consciousness of unfinished, and if hope had ceased, the story would be the determining factors. It would be made up of beings who wait, but do not seek their chances. Points out that the world is not, being, as we warn that the imprisoned man is arrested, it is not stuck. It is this uncertainty that founded the possibilities of realizing these subjects intended changes, life proposals for themselves and families.

It is essential, however, recognize that we are being conditioned by our social affiliations, biological, genetic, historical, but capable of change. The constraints do not define only hinder actions promoting joints tout beings, boosting them. Projects that link the subjects are described as coping possibilities of a society that would probably not welcome them in their reintegration invested, but it is possible to propose actions arising professionals that guide in their expectations.

Freire (1971) points out that it is from man's relationship with reality, it will stimulating it, creating it and recreating it, realizing the man the potential to re-create the relationships and dynamic world. The man is not determined by the world, but part of it in a dynamic process of participation and the reality domination. Emphasizes the idea of resistance to be perceived by the individual not to leave reify, demote to pure object without hope. Incites the man to have a permanent critical attitude, natural attitude to overcome the simple social adjustment.

It is understandable that the educational process in an imprisonment institution is aimed at strengthening selfesteem and self-image issues in students so that they (re)build their identities as outdated in these spaces. The school operates, in this perspective, as a promoter of an unveiling of powers that be, allowing the spill-over effects of these changes.

In this regard, Stobäus \& Mosquera (2012) emphasize that we must urgently consistent emotional education to cognitive aspects. In this sense, also emphasize that it is essential to human aggregate in their professional actions human values as they intertwine, especially in teaching duties.

Approaching to Mosquera (1976)'s work; as one of the theoretical contributions to the development of the article, I address the author of the reference on the incompleteness of man, because according to the author, the adult is a being that juts into the future and the prospects of this work is to understand in what ways education can corroborate alternatives to think that the individual as a becoming.

Mosquera, in this respect, discusses the stages that make up the human development (Stobäus \& Mosquera, 2012: p. 179) states that:

Each time we allow a deeper understanding of a person, do not know her money, not know her superficially, we realize that the person to the nearest, is a mystery, which we know very little, we know evil. We have built a world to ensure that we do not have vision of what the person is.

To try to meet each other, we need to divest ourselves of concepts conceived as true and immutable, to realize that we, teachers, also built us and (re)built us throughout life with positive experiences, or not.

Mosquera (1987) also warns about the impossibility of non-indifference to the other because the other cannot be for us an indifferent object, therefore meet the aspirations of this man who is arrested, part of my human constitution, of a professional career who organized my life as a teacher in adult education schools. Make it known, through the possibility of writing manifestation, will be an unveiling of issues intrinsic to this subject that still 
remains in the dark of his ideal aspirations and social achievements, as a subject of rights in this world of knowledge, constantly denied or neglected.

Mosquera (1987) also addresses the stages that make up the human development and external conditions, the author emphasizes, we realize the biological constitution, the physical and social environment. The internal conditions pervade the character, personality, aspirations, desires, and other factors. The dialogue, he said, is necessary for a number of authentic and renovators principles that constitute the idea of intimacy and appreciation of human beings. The author emphasizes that most of the relationships are subjugated to the transformation of individuals into strangers to their own possibility of communicating in an effective and real way.

We also highlight the importance of self-image and self-esteem as permanent and continuous processes of the human personality, at any stage of life. When it comes to self-image and self-esteem involves stress the importance of the task set to the teacher, because it can reveal to students their latent state improvement, corroborating to reaffirm the positive images that make themselves.

The same author emphasizes that it is a mistake when the Psychology sticks only to the development in the early stages of life, becoming thus in a neglect factor towards this unfinished adult man. Stresses also that is urgent the proposal to rethink about the deep mystery surrounding the unfinished human being and its relations with its development, regardless of historical era and played social role. The age categorization, according to the author, defines adult stages in development stages, but not determined by understanding the variability of relevant issues involving this being (Mosquera, 1987). Points out that every moment of life allows, consequently, new learning (Mosquera, 1984).

In his views, Mosquera (1987: p. 80) points out that "the young adult needs to fight with yourself for determination and harmony in their forces, in a word, must define your personality". The author emphasizes that the adult is facing the appreciation of individuality and a great vitality, supporting bodily efforts. Typically, at this stage, impulsivity enables you to make mistakes.

Each society or cultural group, however, standardize the meanings of adult and settled each step will be an important driving force with this adult boost your life to new challenges. The author explains that the referenced parameters do not establish a single glance directed to this young adult, as relations with the social, historical and cultural environment in which this adult is inserted it adds standards, generates expectations and projects the physical reality, intellectual and this emotional human. The variables are so significant that enter this space with the certainty categorization will lead to questions that resist the ratings.

Following conceptions of Mosquera (1987: p. 84), "the 40 years inaugurate a new phase that is with the existential crisis, feelings of loneliness and radical questioning of life itself'. It also argues that assumption is to assume that the average adult already has structured his life, as also for this reason, feel more attached to standards and obligations that society has imposed. According to the author, this age group, early middle adulthood, changes occur more significantly, because there is the possibility to reap the fruits of the work done, but also think odds and unattainable projects. The decade of the 40 , according to the author, is the stage that both can look at the past to see the future.

At 60 years of age, the average adult prepares for retirement and is aware that he must leave the responsibilities of the tasks exercised for younger people. Old age, says the author, provides loss of physical vitality and the inevitable retirement, coupled with the breakdown of labor relations, productivity and the probable loss of selfimage and self-esteem.

Therefore, following the chronology of ages referendum the research proposal (Mosquera, 1987), because it complicates the task of enlarging it to the socio-anthropological field without losing the focus of the object to be studied: the written as references to be certain knowledge of the imprisoned students. The author therefore proposes age categorizations indicated for research purpose:

- Young adult, 20/25-40 years old;

- Average adult from 40 to 65 years of age;

- Old/Late Adult, from 65 to death.

The explanation for this categorization is the assumption that adolescence is constituted by a social concept and its duration ends only with solving professional problems and affirmation as professional subject.

\section{Methodology}

Data collection sets up exploratory qualitative case study, according Stake (1998), using the Content Analysis 
Technique Bardin (2012), in its three stages (detection of themes, categorization, analysis and inference). The research consists on oral and written narratives from NEEJA Alaor Antonio Terra students, who proposed to participate in the task, providing subsidies to obtain the collected data. The objective, therefore, was through the written narratives (complemented on the oral participations in the classroom) to understand how the Prison Education School could be instituted to assist the students in relation to their expectations with the family and the labor market. The data were collected in the classroom as conversation and redactions, set in a pedagogical proposal, submitted to content analysis, emerging four categories, and here are related the data from the first.

The four categories were these: 1 . Memories about the school space that the subject attended. 2. School references these students attended in the extramural space/prison education. 3. Projects, educational and work opportunities of the students. 4. Reflections on the possibilities that the imprisoned have when leave the prison.

Thus, we had the opportunity, through the oral and written narratives of students from ponder their expectations, when leave the prison grounds. The category selected to compose this project was based on the thematic proposition: What are the projects you have for your life and in what ways can the school help you frequent? We combine thus the established pedagogical knowledge and offered the school the possibility of reference, also the skills for the labor market and vocational courses.

We believe that the human being has the means to rethink their existence, to propose the effective search of more suitable situations for themselves, their families and the community in which he lives.

The research was approved by the Scientific Committee of faculty of Education of PUCRS.

\section{Data Analysis and Discussion}

We start examining the category proposal, emphasizing that the spelling and grammatical errors that appear in the text are those who are in the essays of students, just put them in single quotes. The subjects are numberedfrom 1 to 39, so no identification and texts were removed elements that could be identification data of these subjects.

With data from Category Four: Projects of students NEEJA Alaor Antonio Terra, we now follow to the students' written outcome and we supplement them with authors and finally, then considerations of the doctoral student and his advisor.

Subject 1 says: "my designs are out of here and continue studying and working with a formal contract and return to living with society and living with my family". Subject 2 emphasizes: "the project I have for my life is to study leave here to find a job to work with a formal".

Both subjects relate their formal contract as a proposal for identification, without specifying, however, the kind of work they want, nor desirable skills to achieve it. The conquest of identity through own and to use its profile of work for former prisoners, is another way to resume the broad social environment, to perceive themselves as citizens, gaining respectability for themselves and in the community they are inserted and can act considered to have reached its (re)socialization.

The work permit legitimizes worker claims by inserting it in the visible universe productivity. One of the requirements for the return to crime in the world is on the fact that working life is dissociated from the skills that the graduate has left the prison system. Rare are the professional opportunities that include inmates in prison system. The prison work sometimes becomes alienating real-world community work to receive the detainee. To perceive helpless without real livelihood opportunities for themselves and family, uses the actions that knows and the inevitable, then occurs: recidivism. To reverse this situation the prison system need to enable the acquisition of a profession, within the prison center, review the employment possibilities of the labor market by updating and preparing the detainee for possible professions that would really be enabled.

You can expect a sentenced to evade the system, facing up to the world of work without the minimum conditions to be recognized fit for any activity that requires constant improvement. How to face with these possibilities of social life, during their stay in the prison system, someone provided their food of life, housing and did not allow him to keep reference for you and your family? The prison world keeps alienated incarcerated real life situations, providing it with emergency needs.

The reunion with family could be also a way to insert it in the outside world, gradually, while serving their sentence. No approach situations with family and with the children to prepare to receive them again. The foundations which will host their conduct are referred to as study, family and work, which potentially ensure the stability of life and their proposals. 
Subjects 3, 11, 14, 21 do not mention projects, or refer to the school. It constitutes also concern the lack of expectations of student projects, because if that happens in their lives, it is assumed that education does not realized healthy alternatives for them, or they have not seen in education possibilities. There is apprehension that these subjects leave the prison system without the resumption of family ties, study proposals and work projects.

S 4 believes that "the college can help me a lot out there 'because that' after I started studying my thoughts have changed and hopefully keep it up", 5 emphasizes "the project that the school is giving me today learn more". The subject 6 stands "the school will help me learn what I have not learned years ago. The school can help get me lessons I left behind", 7 ponders "here I am learning things I did not know and when I leave here I will study because of my service”, 8 states “[...] I want to learn more I want to do a course in electrical area I want to improve myself more [...].

Refer to the school as a place of knowledge, designing future learning. Do not allude, however, situations in which the school can influence in achieving a professional improvement.

Subject 9 says "for if I study tomorrow then I can go to college and be someone in life, because the study does not only to learn a lot of things like having a good job and earn a good salary and not have this life we have the crime".

The school's projection as enhancer of possibilities that departs from the criminal life is emphasized and reinforces the idea that wages and jobs are associated with the success of school life. The proposal to join a college, not specified, is also designed to be someone in life. However, this possibility does not guarantee success in a competitive society set as the current.

Subject 10 provides "[...] projects and work and study and not commit more wrong things and do not use drugs in my life”.

The purpose of joining the drug coping process is mentioned as a factor adding to the life that you want to use in the future. The challenge is up a lot, but associated with projects to study and work establishing links for future social reintegration. Equally troubling is the inclusion of young people and adults in prison systems caused by drug use and the surrounding features that it provides. You do not see proper treatment to combat addiction, while they live in prisons.

Subject 12 bails "I'm studying to get out of here the better I got because who was missing was more I'm just ready to work, take care of my daughter and my wife", 13 ensures "the projects I have is learning more and more with the school, to the maximum engage me mature very academically and when I can leave work honestly without causing any problems for my neighbor. And this school I want to change my ideas, I will learn more and more, I'll know to handle my weaknesses my failures. The school is changing my way of thinking about life, changing my way of acting in relation to the next".

S 15 says "today around to retrace new plans and projects for my life because now I have returned to study in this school within the Presidio, I again reflect on my life, and I will believe that if I push myself just a little bit, sure, I'll change my life and drop the hand of crime and be a citizen equal to any other".

The school's relationship with learnings that protrude beyond the prison space is evident in the subjects written, provocative and reflections that contemplate with a healthy life outside of confinement and possible resumption of family relations.

Subject 16 says "I want to go home and put together a nutrition business, knowing that today the qualification course is very important for this business work".

The professional qualification project is perceived as a link to a possible profession. It would be the allocation of directors of prisons to encourage the improvement of work skills, along with the study. In the prison system, however the binomial work-study seems to be disconnected, not providing the convicts the opportunity to work and study, as binomial life proposals.

Subject 17 revealed "[...] I intend to finish school and go out when I want to continue with the studies, because it is never too late to start and my family also depends on it. The school learned a lot from this opportunity". Stresses the binding family ties and relates them to their life projects.

S 18 shows: "my designs are: Working away from crime, further studies, so I attend this school".

The following expectations of a life that will keep you away from chances of being a recidivist is highlighted, but does not mention how you want to do it. Recidivism sometimes occurs by the lack of integration prospects in the labor market and the lack of direction to your expectations. Adaptation to the prison space is linked to the lack of adaptation to free life, contributing to recidivism and return to the world of crime. In this process of adaptation and maladjustment, is configured the way for the return to prison spaces. 
Subject 19 says "I always dreamed of becoming a civil engineer, I know that there is still time and I have a lot to learn".

The purpose of becoming an engineer is linked to consciousness time you have, in your favor.

S 20 revealed "my designs are to have a quiet life, with two children can have my house and get out of this little life that leads nowhere. You cannot help me in almost anything if I'm not interested; it is that I have to help $m e$ ".

The student recognizes the participatory response threshold of the school very clearly. You realize that the interest should be related to the availability that has to face situations that led to imprisonment. The relationship of peaceful life, home and children led him to realize the possibilities of family remakes. Put your expectations in their own determinations to perceive changes as opportunities.

Subject 22 emphasizes, "my goal and have higher education be a law degree and now imprisoned want to at least finish high school", S 24 reveals "make law school and take home to learn what I have not learned".

The right course has in the ideas of some students, the desire to get closer to the world of law. The ability to understand the procedural universe, approach and appropriate the suitable vocabulary are, in many cases, the urgent desire. In the prison system, to be added to the universe of legal understandings constitutes a sign of independence and dialogue compatible with lawyers circulating in the room. The speech of the subject 24, however, adds the desire to own a home. The house itself is the desire of belonging, of being connected to a place of being constituted by object as a form of identification.

The account of the subject 23 "my project for my life are first come out here and change your life. The school here can really help me to follow in my life because I can concentrate on my studies already here and follow up when you leave. Who knows studies now you can get a good job".

The school is associated with the ability to achieve life-changing projects, but does not mention what projects, however, emphasize that you want to continue their education, linking project future jobs.

S 25 states, "I do not know how this school could help me since I'm stuck. But I will not give up being a Physics Education teacher".

Mentions school inaction by being arrested, however, establishing his desire to be a physical education teacher. In apparent contradiction of positions, it is clear that the school for more deadly it is, according to the argument, established way of designing your wishes to come to be, though deprived of freedom. Relativized, thereby, the power of the school he attends.

Subject 26 says "I'll turn truck out of here I'll hit the road and redo my life and lost time".

The possibility of becoming a truck driver underlies the idea of freedom contained in this writing. Road, redoing life and recovery of lost time in line make up the desire for liberation of all commitments. No mention, however, as will desire to be accomplished.

S 27 revealed: "leave this place touching the firm that got out there to spend as much time with my daughter have to show the right and wrong encourage the study to others for me was very good".

The projects are located in the work, the firm that owns and daughter. The claim to be an encourager of good practice for the daughter, is a promoter of possibilities, also with reference to the studies.

S 28 states, "my goal is to correctly complete high school so in the near future is to jump in every way in my life".

The immediate goal is in the completion of high school, but does not mention the project to life, only emphasizes that it is through the study will have the possibility of a radical change in life.

The subject's 29 statement was: "I want to finish high school, to prove the ESMS at the end of the year and when I go free, do a technical course or an engineering college, or architecture. The school will help prepare me for tomorrow at a college".

The National Exam Education Medium-ESMS, referred to by the student, already constitutes a real opportunity for internal systems in prisons, and the description is made by the responsible in each institution. The graduates reflect on the immersion opportunities in society, but it is necessary that the whole community be allowed to think of the need for paradigm change for the good of prisoners, or not. The authorities are ahead of penal institutions are constantly challenged to security issues in favor of an effective, but not lasting prison order. The prison order also established with prospects for behavior change in future possibilities and rebuilding lives.

The subject 30 says, "Living with my family to raise my children and now they are grown up, have an example I like a right father. Finish my studies and start a business".

Family restructuring projects, be an exemplary father to the children and study, are guiding proposals for fu- 
ture life, but does not refer to the business you want.

Subject 31 states "my project is living one day after another and keep trying to study, so I might change my future because this has greatly improved from the time that I went back to school”.

Daily life is part of the urgent project of life, does not, however, related to the future distant, but immediate. Banks in school the option you probably have, because the alternatives are made about the odds.

The statement of subject 32 was: "I want to do college entrance in college and graduate in law or administration, and this school today that I have helped me and recapitulate matter seen but not remembered, but that is contributing in an exceptional way for a new direction in my life and my future projects a fresh start".

Prospects for university courses range from two possibilities: right, or administration. The school is referred to as driving knowledge already forgotten, but potentially remade and contributions to a fresh start.

The account of the S 33 was: "my life plan is to return to my service area that is television".

The life project is built on a unique possibility. The professional, however, that is not inserted and updated in the labor market will certainly be relegated, because it is dynamic, select the competence and requires constant updating.

S 34 said, "my project is to place a mobile shop of exclusive shoes. The school today is helping me a lot because the teachers are very dedicated and charge us information”.

A single project supports the proposed work of this subject, and also can cause conflict situations, when faced with the constant dynamism of the labor market. It would be the school's role to provide enlightening events and the possibilities of employment and income for the imprisoned. The managers of the prison systems could offer training courses consistent with their skills. Between the idealized and what the labor market supply, sometimes there is a huge gap that leads to abandonment of cherished dreams. The subject reveals the role of teachers as information promoters.

S 35 says: “as for this school I'm currently attending, for today it is indispensable”.

Does not mention, however, aspects of the school that do not matter.

The account of subject 36 was: "when you leave school I want to use something maybe open a business that gives enough money to improve my life and my family".

A business with sufficient income is mentioned but does not specify what will be. Does not mention the importance of school for their future projects, but mentions the family and concern to provide improvements to it. It is necessary to clarify that the financial profitability issues should be consistent with the regulatory requirements of the market. One has to think of reconciling expectations with job opportunities and income, to escape the prison system.

Subject 37 commented, "I do not even have formed me anything until now, my desire to have a degree still alive, I have plans for the future”.

The higher education mentioned is cherished, as a project for the future. It does not mention the course, however, not the projects aims.

S 38 revealed: "I want to work if I get out of here in time in the naval pole, as welder".

The welder craft is directed to the naval polo, but does not specify how to do that their projects are consolidated. The name, however, the condition, "if I get out of here in time" establishes the condition in which it is as limiting to its proposal.

Subject 39 asserts: "project one-1 exit and continue working with some knowledge more, concluding the High School I can attend courses I have been interested for some time. The school I attend can help me in completing the course and in the vision that I have now that I possess ability that did not know".

The school appears as a possibility for the scope of their proposals. The name you want to continue working, does not mention, however, their prospects. The school is mentioned as a promoter of knowledge, allowing you to envision development of skills that have unknown.

The subjects of the writings have ages ranging from 21 to 55 years, in the Middle Adulthood; however, go beyond the linear development expectations, constituting a field of study inherent situation. Do you see yourself in the situation of incompleteness and life proposals; see for themselves that possibilities do not end in the age issues. They think of themselves as probabilities, and in the writings emphasize that time has not dismissed the willpower to return to family life, to rethink, as subjects of actions and transformations. They emphasize also that the misunderstandings related to immaturity and impulsivity led them to the place of segregation in which they are. They admit a fresh start, with less opportunity for error, anchored in the possibility that the Prison Education, this made, gives opportunity. 
The alluded projects for these students, the prison enclosure, become innocuous, if not accompanied by professionals who subsidize their expectations. We consider that the new information tools, for example, are taught predominantly or exclusively in workspaces. Outside the labor market, access to these tools is costly and difficult. The process of creation and production of computerized machine tools calls for major financial conglomerates scientific and technological improvements. Educational processes and ongoing training imposes to the costs of production and reproduction of the labor force, and constitute competition and exclusion factors.

Professional qualifications and familiarity with new professional tools accelerate, add up and alternate throughout the life of a single worker. Qualifications that become unnecessary are terminated before the end of the life of a professional. Alternatively, the employee permanently invests in their (re)professionalization or becomes obsolete even before aging. Workers outside the labor market, alienated from the productive and social networking process are helpless in the face of rapid technological change.

The sociologist Bauman (2008: p. 33), the work Individualized society: counted lives and stories lived, establishes a path of market analysis and labor support. Emphasizes the changes in the world of work that have led to the changes and alternatives to modern industrialized society. The company's "heavy modernity" becomes digested and embraced by the "liquid modernity" that requires flexibility actions, constant demand for labor markets, increasingly distant from what it claims to be, the containment system.

The model or models for Prison Education Schools would need to introduce, thus, different levels of information for citizens and professional, according to the Education of the student, seeking their (re)professionalization for work and citizenship through a qualifying training, multidisciplinary and with responsibility. The meeting the demands of specific social groups, such as prisoners, is located in the Brazilian case, the list of state duties related to the reproduction of the labor force.

The project to think about educational opportunities in the gaucho prison system is rooted in constant inserts while teaching in the various prison spaces in which he worked. I realized at the time he needed collude school activities with the work aspirations that students had. I understood, likewise, that the school could provide instructional tools that potentiates actors of their own experiences of workers. Sometimes realized that Education away to the ideals that students sought at school. Thus, the research carried out intended to verify the expectations that students have, knowing beings who seek, who are experienced, and who want to become, at any stage of life, in any circumstances where they are. I think this man in his constant search, in their personal aspirations, work, and see that more than a utopia school can be driving possibilities and constant remakes.

\section{Conclusion}

Resuming the analysis of the fourth analytical category, projects that the egress of the prison system articulates, and our reflections about the written narratives of the same, we synthesized the following proposals:

1. Recollections about the educational space of students and their teachers, as well as family, work, leisure, among others.

2. Resumption of extramural school (here understood as the one that can and should continue studying when leaving the prison system) as a power in the choices of decisions which the subjects had in their lives.

3. Relations between teachers and students (before, during and after).

4. Rethinking projects for the life of the egress of the prison system.

5. (Re)thinking the binomial Education and Professionalization, constituting a basic instrumentation for all involved.

6. Promoting significant curriculum and new curriculum guidelines, with reorganization and new practices.

7. Having flexible service schedules and classes.

8. Continuity studies after leaving the prison system in extramural schools.

9. To all reflect about this instigator question: reform or innovate?

10. Remembering the continuous oscillation between the possible and feasible.

11. Final Contribution: add a discussion of extramural and Prison Education School, because they are aggregated to the success or otherwise of the students.

Students attending the NEEJA Alaor Antonio Terra are perceived as guilty of situations that away from school, and approach waywardness that leads them to incarceration. There are mitigating this finding for the crime that plagues society, but a proposal for (re)think on the urgent social change, which can start by teaching that incorporates the perspectives of students and the teacher provides constant updating. 
There is no measure to be a Prison Education School without enable reflections on extramural education, acting as consequences and intertwined. It is to rethink about this student in a family and social context that needs to be rescued to school life, with projects involving family, that approach the school. It is also impossible to reflect on the school without putting it in an interactive context with society. The arrest demonstrates the complete failure of a society that allowed individuals do not find insertion space in it, it becomes invisible and thus should remain until release from prison, when will try to find its place again in this universe that already disowns previously.

The alternatives are almost non-existent, then it resorts to what has already learned before imprisonment, his departure and the vicious cycle probably are complemented with recidivism.

We may not have the full answer to the questions of this magnitude, but I think for many years on a possible proposal for a human school, healthy, aggregator and education within the prison system. The school, a place of welcome, aggregates the reveries of the past; it is quoted and cherished as healthy refuge in family-social society in which the student is inserted. This testimony of students, once again, confirms the premise that education is the essential support that makes a more humane and potentially happy society.

\title{
References
}

Bardin, L. (2012). Análise de conteúdo [Content analysis] (3rd ed.). São Paulo: Almedina.

Bauman, Z. (2008). A sociedade individualizada: Vidas contadas e Histórias de Vida [The Individualized Society: Counted Lives and Life Stories]. Rio de Janeiro: Zahar.

Freire, P. (1971). Educação como Prática da Liberdade [Education as Freedom Practice] (3rd ed.). Rio de Janeiro: Paz e Terra.

Freire, P. (1997). Política e Educação [Politics and Education]. São Paulo: Cortez.

Mosquera, J. J. M. (1984). Psicodinâmica do aprender [Psychodynamics of Learning] (3rd ed.). Porto Alegre: Sulina.

Mosquera, J. J. M. (1976). O professor como pessoa [The Teacher as a Person]. Porto Alegre: Sulina.

Mosquera, J. J. M. (1987). Vida adulta: Personalidade e desenvolvimento [Adult Life: Personality and Development] (3rd ed.). Porto Alegre: Sulina.

Stake, R. E. (1998). Estudio de caso [Case Study]. Madrid: Morata.

Stobäus, C. D., \& Mosquera, J. J. M. (2012). Educação especial, em direção à educação inclusiva [Special Education: Towards Full Inclusion] (3rd ed.). Porto Alegre: EdiPUCRS.

Tavares, M. C. (2009). Reflexões sobre a escola: Com a Palavra os Pais, os Alunos e os Professores do Ensino Fundamental [Reflections about Schools: With the Word of Parents, Students and Primary School Teachers]. Curitiba: Juruá.

Valmorbida, N. M. (2016). Proposta inovadora para uma escola intramuros: Estudo de caso em Porto Alegre-RS [Innovative Proposal for an Intramural/Prison Education School: Case Study in Porto Alegre-RS]. Tese (Doutorado em Educação) —Faculdade de Educação da PUCRS, Porto Alegre-RS.

\section{Scientific Research Publishing}

\section{Submit or recommend next manuscript to SCIRP and we will provide best service for you:}

\author{
Accepting pre-submission inquiries through Email, Facebook, Linkedin, Twitter, etc \\ A wide selection of journals (inclusive of 9 subjects, more than 200 journals) \\ Providing a 24-hour high-quality service \\ User-friendly online submission system \\ Fair and swift peer-review system \\ Efficient typesetting and proofreading procedure \\ Display of the result of downloads and visits, as well as the number of cited articles \\ Maximum dissemination of your research work
}

Submit your manuscript at: http://papersubmission.scirp.org/ 